\title{
ОЦІНКА ФАРМАКОТЕРАПЕВТИЧНОЇ ЕФЕКТИВНОСТІ ГЛУТАРГІНУ Й ЕРБІСОЛУ В МІЖРЕЦИДИВНОМУ ПЕРІОДІ ХРОНІЧНОЇ ЕКЗЕМИ
}

\section{Оцінка фрармакотерапевтичної ефективності глутаргіну й ербісолу в міжрецидивному періоді хронічної екземи}

Л. В. Черкашина ${ }^{1}$, Мескаль Ахмад Махмуд Мамдух², Л. В. Куц², Н. В. Деміхова², К. В. Куц²

Харківська медична академія післядипломної освіти мОЗ України ${ }^{1}$

Сумський державний університет МОН України ${ }^{2}$

Резюме. Потреба у постійному та довготривалому спостереженні пацієнтів із хронічною екземою (XE) на рівні первинної медико-санітарної допомоги актуалізує необхідність удосконалення лікування саме в період між рецидивами захворювання. Актуальним є визначення фрармакотерапевтичних ефектів антиоксидантних засобів та засобів адаптогенного впливу, передусім стосовно фрормування у цих хворих метаболічних компенсаторних реакцій як запоруки подовження термінів клінічної ремісії хронічної екземи.

Мета дослідження - оцінити ефрективність дифреренційованих терапевтичних комплексів на рівні системи неспециорічного імунного захисту та окиснювального гомеостазу в пацієнтів із хронічною екземою в міжрецидивний період.

Матеріали і методи. У дослідженні задіяно 75 пацієнтів із XE, яких поділили на три групи залежно від складу диференційованих терапевтичних комплексів (ДТК), і у міжрецидивний період проведено лікування, зокрема у пацієнтів першої клінічної групи (KГ $)$ застосовано препарат «Глутаргін» (0,25 мг тричі на добу впродовж 3-х тижнів), у другій (КГ $)$ - препарат «Ербісол» (щоденно 2,0 мл внутрішньом'язово упродовж трьох тижнів), при лікуванні пацієнтів третьої групи $\left(К \Gamma_{z}\right)$ застосовано препарати «Глутаргін» та «Ербісол». Фармакотерапевтичну ефрективнівність ДТК оцінювали за показниками стану системи ОГ та СНІ3.

Результати. Досліджено фрармакотерапевтичні ефректи препаратів «Глутаргін» та «Ербісол» у хворих на хронічну екзему в міжрецидивному періоді та доведено, що найбільш ефективним $є$ їх застосування в єдиному терапевтичному комплексі, що дозволяє досягати адаптаційних та компенсаторних реакцій системи окиснювального гомеостазу та системи неспецифрічного імунного захисту в більшості пацієнтів 3 одночасним фрормуванням метаболічних резервів адапmauiï.
Evaluation of the pharmacotherapeutic efficacy of glutargin and erbisol in the interrecurrent period of chronic eczema

L. V. Cherkashyna ${ }^{1}$, Methkal Ahmad Mahmoud Mamduh' $^{2}$, L.V. Kuts2, N. V. Demikhova ${ }^{2}$, K. V. Kuts ${ }^{2}$

Kharkiv Medical Academy of Postgraduate Education ${ }^{1}$ Sumy State University ${ }^{2}$

e-mail: serg_shklyar@ukr.net

Summary. The need for constant and long-term monitoring of patients with chronic eczema (CE) at the level of primary health care highlights the need to improve treatment in the period between relapses. It is important to determine the pharmacotherapeutic effects of antioxidants and adaptogenic agents, especially in relation to the formation of metabolic compensatory reactions in patients with chronic eczema, as a guarantee of prolongation of clinical remission of chronic eczema.

The aim of the study - to evaluate the effectiveness of differentiated therapeutic complexes at the level of the system of nonspecific immune defense and oxidative homeostasis in patients with chronic eczema in the interrecurrent period.

Materials and Methods. The study involved 75 patients with CE, who were divided into three groups depending on the composition of differentiated therapeutic complexes (DTC), and in the interrelapse period was treated, in particular in patients of the clinical group 1 (CG1) used the Glutargin drug (0.25 mg three times) per day for 3 weeks), in the group 2 (CG2) - Erbisol drug (daily $2.0 \mathrm{ml}$ intramuscularly for three weeks), in the treatment of patients of the group 3 (CG3) used Glutargin and Erbisol drugs. The pharmacotherapeutic efficacy of DTC was assessed by indicators of the state of the $\mathrm{OH}$ system and non-specific immune system protection.

Results. The pharmacotherapeutic effects of Glutargin and Erbisol in patients with chronic eczema in the interrecurrent period were studied and proved to be the most effective in a single therapeutic complex, which allows to achieve adaptive and compensatory reactions of the oxidative homeostasis system and the immune system patients with simultaneous formation of metabolic reserves of adaptation.

Conclusions. It was found that the use of Glutargin slightly increases the frequency of persons with functional 
Висновки. З'ясовано, що при використанні препарату «Глутаргін» дещо зростає частота осіб із функціональною компенсацією та зменшується питома вага хворих з реакціями метаболічного дисбалансу ( $p>0,05)$; узагальнений індекс ефрективності у клінічній групі (КГ), становить: $I_{\text {Еог }}=1,11$. При використанні препарату «Ербісол» достовірно зростає частота осіб із фрунциінальною компенсацією та зменшується частка хворих з реакціями метаболічного дисбалансу $(p<0,05) ;$ узагальнений індекс еорективності у КГ становить: $I_{\text {Его }}=1,38$. При використанні комплексу (препарати «Глутаргін» $i$ «Ербісол») достовірно зростає частота осіб з функціональною компенсацією $(p<0,05)$ та зменшується частка хворих із реакціями метаболічного дисбалансу $(p<0,01) ;$ узагальнений індекс ефрективності у КГ становить: $I_{\text {вго }}=1,71$. Buявлено, що при використанні всіх трьох терапевтичних комплексів зростає частота хворих з імунорегуляторною компенсацією, зменшується питома вага хворих із реакціями імунорегуляторного дисбалансу $(p<0,05)$.

Ключові слова: хронічна екзема; лікування; антиоксиданти; адаптогени.

\section{ВСТУП}

Хронічна екзема (XE) - одне із найбільш поширених захворювань, загальна поширеність їі серед дорослого населення України сягає рівня 15,0 \%о та різниться залежно від віково-статевої структури популяційних груп, екологічних особливостей регіону, застосовуваних методів діагностики та якості лікувально-діагностичного процесу [3]. В патогенезі XE має місце поєднання порушень фрункціонування системи неспецифрічного імунного захисту, окиснювального гомеостазу (ОГ), вегетативно-судинних та нейроендокринних змін на тлі спадкового обтяження за аутосомно-домінантним типом $[16,17]$. Потреба у постійному та довготривалому спостереженні за пацієнтами із XE на рівні первинної медико-санітарної допомоги (ПМСД) актуалізує необхідність удосконалення лікування саме в період між рецидивами захворювання. Інтегроване ведення пацієнтів iз XE визначає також потребу в удосконаленні та персонісрікації лікування, включаючи і фрармакотерапевтичну корекцію розладів системи неспецифрічного імунного захисту (CHI3) та окиснювального гомеостазу (ОГ) [15-17] в період між рецидивами XE. Основними завданнями лікаря загальної практики - сімейної медицини (ЗПСМ) поряд з іншим є визначенням обсягів лікувально-профрілактичних заходів, спрямованих на досягнення комплаєнсу, психосоціальну допомогу пацієнтам та компенсацію можливих фрункціональних та метаболічних розладів [3]. У вказаному контексті актуальним $€$ визначення фрармакотерапевтичних ефектів (ФТЕ) антиоксидантних засобів (АОЗ) та засобів адаптогенного впливу, передусім стосовно фоормування у хворих на XE метаболічних компенсаторних реакцій як запоруки подовження термінів клінічної ремісії XE $[15,16]$. compensation and decreases the proportion of patients with metabolic imbalance reactions ( $p>0.05$ ); the generalized efficiency index for clinical group (CG1) is 1.11. When using Erbisol the frequency of persons with functional compensation significantly increases and the proportion of patients with metabolic imbalance reactions decreases $(p<0.05)$; the generalized efficiency index for CG2 is 1.38. When using the complex (Glutargin and Erbisol) significantly increases the frequency of persons with functional compensation $(p<0.05)$ and decreases the proportion of patients with metabolic imbalance reactions $(p<0.01)$; the generalized efficiency index for CG3 is 1.71. It was found that when using all three therapeutic complexes, the frequency of patients with immunoregulatory compensation increases, the proportion of patients with immunoregulatory imbalance reactions decreases $(p<0.05)$

Key words: chronic eczema; treatment; antioxidants; adaptogens.

Метою дослідження було оцінити ефрективність дифреренційованих терапевтичних комплексів на рівні системи неспецифічного імунного захисту та окиснювального гомеостазу в пацієнтів із хронічною екземою в міжрецидивний період.

\section{МАТЕРІАЛИ I МЕТОДИ}

У дослідженні задіяно 75 пацієнтів із XЕ, яких поділили на три групи залежно від складу диференційованих терапевтичних комплексів (ДТК), і у міжрецидивний період проведено лікування, зокрема у пацієнтів першої клінічної групи $\left(\mathrm{K}_{1}\right)$ застосовано препарат «Глутаргін» (0,25 мг тричі на добу впродовж 3-х тижнів), у другій (КГ 2 - препарат «Ербісол» (щоденно 2,0 мл внутрішньом'язово упродовж трьох тижнів), при лікуваанні пацієнтів третьої групи (КГ ${ }_{3}$ застосовано препарати «Глутаргін» та «Ербісол». Фармакотерапевтичну есрективнівність ДТК оцінювали за показниками стану системи ОГ та СНІ3.

До та після закінчення курсу лікування, окрім загальноклінічних методів, виконано дослідження стану ОГ на рівні трьох базових підсистем: окисномодисрікованих білків (ОМБ) та нуклеїнових кислот (НК), біоенергетики клітин, фрерментативного ланцюга та пероксидного окиснення ліпідів (ПОЛ) мембран клітин і NO-залежних метаболітів. Стан ферментативного ланцюга АОЗ оцінювали за активністю супероксиддисмутази (СОД), глутатіонпероксидази (ГПР), каталази (Кат) у еритроцитах та $\alpha$-токофреролу ацетату ( $\alpha$-ТФА) у сироватці крові. Вміст СОД визначали неферментним методом [8, 10], ГПР - за методом R. Olinescu [5, 12]; принцип методу заснований на виявленні витраченого глутатіону; вміст Кат визначали спектрофотометрично 
$[6,12]$. Визначення $\alpha$-ТФА виконано спектрофотометрично [5], вміст МДА у плазмі визначено за методом І. Д. Стальної та М. С. Гаришвілі [6]. Вміст ДК визначали в плазмі [11], вміст ТК в плазмі виконували аналогічно ДК, але на відміну від ДК, у якості фонової проби використано гептан, а рівень NO-залежних метаболітів - за методикою Грисса [7]. Дослідження ОМБ та НК виконано за показниками вмісту білкових компонентів у сироватці крові - 2,4 - динітрофенілгідрозонів (ДНФГ) та альдегідних і карбонільних продуктів ОМБ у спонтанних та індукованих залізом реакціях [9]. Ступінь окисної деструкції визначали (залежно від довжини хвилі спектрофотометра) дрібні ( $\lambda=254$ нм) ОМБ, виявлені в індукованих реакціях $\left(I_{д}\right)$, середні $(\lambda=270$ нм) ОМБ, виявлені в індукованих реакціях $\left(\mathrm{I}_{\mathrm{C}}\right)$, крупні $(\lambda=280$ нм) ОМБ, виявлені в індукованих реакціях $\left(\mathrm{I}_{\mathrm{k}}\right)$ та аналогічні показники у спонтанних реакціях $\left(\mathrm{C}_{\mathrm{K}}, \mathrm{C}_{\mathrm{C}}, \mathrm{C}_{\mathrm{f}}\right)[1,4]$. Рівень вмісту окисномодифрікованих НК (ОМНК) оцінювали за їх екскреторним (у сечі) індикатором - вмістом 8-гідроксигуаніну (8ГГ) у добовій сечі методом хроматографії на пластинках"Силуфол" [2]; у якості хроматографічного стандарту застосовано 8-ГГ із перерахунком у нмоль $/ \mathrm{cm}^{3}$. Оцінку активності аеробного та анаеробного окиснення виконано шляхом визначення вмісту малату (М), пірувату (П), лактату (Л) у еритроцитах [14]. Рівень вмісту аденілових нуклеотидів визначали хроматографічним методом в системі діоксан-ізопропанол-вода-аміак (4:2:4:1), а ідентифікацію аденозиндифоссрорної (АДФ), аденозинмонофросфрорної (АМФ) та аденозинтрифоосфорної (АТФ) кислот виконано в УФ-зоні на «УФС-365» при $\lambda=260$ нм.

Кров для імунологічних досліджень забирали 3 ліктьової вени вранці натще. Кількісний вміст Т-лімсроцитів $\left(\mathrm{CD}_{3+}\right)$, їх субпопуляцій $\left(\mathrm{CD}_{4+}\right.$ и $\left.\mathrm{CD}_{8_{+}}\right)$ та В-лімфоцитів ( $\left.\mathrm{CD}_{19+}\right)$ визначали методом непрямої мембранної імунофлюоресценції за допомогою моноклональних антитіл $\mathrm{CD}_{3+}, \mathrm{CD}_{4+}, \mathrm{CD}_{8+}, \mathrm{CD}_{19+}$ (НПЦ «МедБиоСпектр»). Чисельність Т-акт субпопуляції лімсроцитів визначали в реакції розеткоутворення з еритроцитами барана. Про порушення експресії рецепторів на імунокомпетентні клітини (IKK) робили висновок на підставі наявності підвищення питомої ваги E-POK та $\mathrm{CD}_{3+}$-клітин в суспензії лімфроцитів після їх інкубації з $\mathrm{PHK}$ азою. Функціональну активність ІКК оцінювали за рівнем спонтанної проліферації лімфоцитів (СПЛ) та за показником інтенсивності проліферації під впливом ФГА. Вміст сироваткових (IgG, IgA, IgM) та секреторного імуноглобуліну (slgA) у слині визначали спектрофотометрично. Для оцінки фрагоцитарної та метаболічної активності нейтрофрілів визначали фрагоцитарне число (ФЧ - кількість клітин, які фрагоцитували) та орагоцитарний індекс (ФІ); метаболічну активність - за спонтанним та індукованим НСТ-тестом; індекс стимуляції (IC НCT) розраховували як співвідношення показників індукованого (іНСТ) та спонтанного (сНСТ) тестів. При виконанні дослідження застосовано клініко-статистичні методи: варіаційна статистика з оцінкою достовірності одержаних результатів [13].

\section{РЕЗУЛЬТАТИ Й ОБГОВОРЕННЯ}

Зміни показників стану ферментативного ланцюга АОЗ серед 25 пацієнтів із XЕ, під впливом ДТК (препарат «Глутатіон») характеризувись достовірними ФТЕ: зростанням активності СОД (до лікування $(158,2 \pm 2,05)$ ум. од./хв, після - $(222,8 \pm 6,2)$ ум. од./хв, p<0,01), КАТ (до лікування - $(6,24 \pm 0,04)$ ум. од./хв, після - $(12,63 \pm 0,40)$ ум. од./хв, p<0,01), ГПР (до лікування - $(32,46 \pm 0,21)$ ум. од./хв, після - $(58,3 \pm 1,2)$ ум. од./Хв, p<0,01) і вмісту $\alpha$-ТФА (до лікування $(1,058 \pm 0,010)$ мкмоль/дм³ ${ }^{3}$ після - $(2,041 \pm 0,030)$ мкмоль/дм ${ }^{3}$ р<0,01) при зменшенні вмісту ДК (до лікування - $(0,495 \pm 0,010)$ мкмоль/дм ${ }^{3}$, після $(0,304 \pm 0,014)$ мкмоль/дм³ $\left.{ }^{3}, p<0,01\right)$, МДА (до лікування - $(0,812 \pm 0,005)$ мкмоль $/$ дм $^{3}$, після - $(0,423 \pm 0,023)$ мкмоль/дм ${ }^{3}$, р<0,01), ТК (до - $(0,320 \pm 0,006)$ мкмоль/ дм $^{3}$, після - $(0,193 \pm 0,010)$ мкмоль/дм $\left.{ }^{3}, \mathrm{p}<0,01\right)$ та NOзалежних метаболітів (до лікування - $(33,48 \pm 0,61)$ мкмоль/дм ${ }^{3}$, після - $(16,52 \pm 0,18)$ мкмоль/дм $\left.{ }^{3}, p<0,01\right)$. Найбільш виразний ФТЕ ( $p<0,001)$ досягнуто за рахунок зростання вмісту КАТ (зріс на 102,0 \%) та зменшення вмісту (в 2 рази) NO-залежних метаболітів

Серед пацієнтів цієї КГ зареєстровано зростання питомої ваги $\mathrm{T}_{\text {акт }}$ лімсроцитів (3 $(31,2 \pm 0,9) \%$ до $(34,3 \pm 1,1) \%, p<0,05)$, зменшення рівня СПЛ (3 $(3,0 \pm 0,03) \times 100$ імп./Хв до $(1,0 \pm 0,2) \times 100$ імп./Хв,

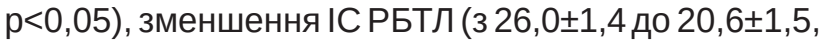
p<0,01). На рівні В-ланцюга, значимих ФТЕ не зареєстровано, окрім достовірного зменшення показника спонтанного НСТ-тесту $(3(16,1 \pm 0,6) \%$ до $(12,7 \pm 0,8) \%, p<0,05)$.

Зміни показників стану ферментативного ланцюга AO3 серед 23 пацієнтів із XE, під впливом ДТК 2 (препарат «Ербісол») характеризувись достовірними ФТЕ: зростанням активності СОД (до лікування - $(159,3 \pm 0,92)$ ум. од./хв, після - $(227,2 \pm 4,2)$ ум. од./Хв, р<0,01), КАТ (до лікування - $(6,12 \pm 0,05)$ ум. од./Хв, після - $(12,46 \pm 0,34)$ ум. од./хв, $p<0,01)$, ГПР (до лікування - $(32,09 \pm 0,24)$ ум. од./хв, після $(59,14 \pm 1,02)$ ум. од./Хв, p<0,01) і вмісту $\alpha$-ТФА (до лікування - $(1,065 \pm 0,009)$ мкмоль/дм ${ }^{3}$, після $(2,042 \pm 0,034)$ мкмоль/дм³ $\left.{ }^{3}, p<0,01\right) 3$ одночасним зменшенням вмісту ДК (до лікування - $(0,523 \pm 0,009)$ мкмоль/дм ${ }^{3}$, після - $(0,281 \pm 0,012)$ мкмоль/дм ${ }^{3}$, р<0,01), МДА (до лікування - $(0,817 \pm 0,002)$ мкмоль/ дм $^{3}$, після - $(0,400 \pm 0,017)$ мкмоль/дм $\left.{ }^{3}, p<0,01\right)$, ТК (до лікування - $(0,324 \pm 0,005)$ мкмоль/дм³ $(0,169 \pm 0,007)$ мкмоль/дм³ ${ }^{2}$ p <0,01) та NO-метаболітів (до лікування - $(31,07 \pm 0,16)$ мкмоль/дм³ ${ }^{3}$ після $(17,01 \pm 0,22)$ мкмоль/дм³ ${ }^{3}$ р<0,01). Найбільш вираз- 
ний ФТЕ $(p<0,001)$ досягнуто за рахунок зростання активності КАТ (на 103,0 \%) та зменшення вмісту (в 2,0 рази) МДА.

Серед пацієнтів цієї КГ зареєстровано зростання питомої ваги $\mathrm{T}_{\text {акт }}$ лімсроцитів (3 $(30,3 \pm 0,9) \%$ до $(35,6 \pm 0,5) \%, p<0,05)$, зростання питомої ваги $\mathrm{CD}_{3+}$ клітин (3 $(45,8 \pm 0,5) \%$ до $(53,6 \pm 0,5) \%, p<0,05)$ та питомої ваги $\mathrm{CD}_{4+}$-клітин (3 $(32,3 \pm 1,2) \%$ до $(36,7 \pm 0,9) \%, p<0,05)$. Під впливом ДТК 2 також

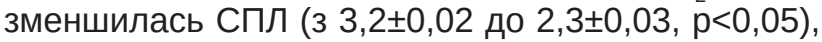

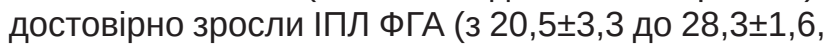
p<0,05) та індекс стимуляції в РБТЛ (3 10,3 $\pm 1,2$ до $18,1 \pm 0,9, p<0,05)$. Окрім того, на рівні В-ланцюга, ФТЕ проявився зростанням показників спонтанного (з $12,4 \pm 0,9$ до $17,5 \pm 0,3, p<0,05$ ) та індукованого

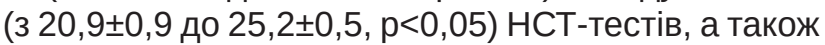
Фч (відповідно $(44,3 \pm 1,3) \%$ та $(51,6 \pm 1,6) \%$,

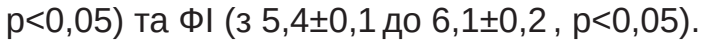

Зміни показників стану ферментативного ланцюга АОЗ серед 27 пацієнтів із XЕ під впливом ДТК (препарат «Глутаргін» + препарат «Ербісол») характеризувись достовірними ФТЕ: зростанням активності СОД (до лікування - $(157,9 \pm 1,56)$ ум. од./Хв, після - $(232,0 \pm 6,2)$ ум. од./хв, p<0,01), КАТ (до лікування - $(6,16 \pm 0,08)$ ум. од./Хв, після - $(13,54 \pm 0,36)$ ум. од./хв, р<0,01), ГПР (до лікування - $(32,50 \pm 0,55)$ ум. од./хв, після - $(61,19 \pm 1,62)$ ум. од./хв, p<0,01) i вмісту а-ТФА (до лікування - $(1,045 \pm 0,02)$ мкмоль/ дм $^{3}$, після - $(2,130 \pm 0,06)$ мкмоль/дм³ $\left.{ }^{3}, \mathrm{p}<0,01\right)$ з одночасним зменшенням вмісту ДК (до лікування $(0,508 \pm 0,017)$ мкмоль/дм ${ }^{3}$, після - $(0,257 \pm 0,021)$ мкмоль/дм ${ }^{3}, \quad$ р<0,01), МДА (до лікування $(0,813 \pm 0,009)$ мкмоль/дм³ ${ }^{3}$ після - $(0,359 \pm 0,019)$ мкмоль/дм ${ }^{3}$, р<0,01), ТК (до - $(0,314 \pm 0,02)$ мкмоль/ дм³ $^{3}$ після - $(0,131 \pm 0,01)$ мкмоль/дм³ $\left.{ }^{3}, \mathrm{p}<0,01\right)$ та NOметаболітів (до лікування - $(30,98 \pm 0,35)$ мкмоль/дм ${ }^{3}$, після - $(16,73 \pm 1,07)$ мкмоль/дм³ ${ }^{3}$, p<0,01). Найбільш вираженого ФТЕ $(p<0,001)$ досягнуто за рахунок зростання вмісту (в 2,5 раза) КАТ та зменшення вмісту (в 2,4 раза) ТК. Отже, ефективність ДТК $-Д Т K_{2}$ на рівні фрерментативного ланцюга про-, антиоксидантного захисту та на рівні метаболічних процесів, пов'язаних із пероксидацією фоосфоліпідів мембран клітин у хворих на ХЕ проявляється низкою достовірних ФТЕ, які характеризуються активацію фрерментативного ланцюга АОЗ.

Серед пацієнтів цієї КГ зареєстровано зростання питомої ваги $\mathrm{T}_{\text {акт }}$ лімфроцитів $(3(42,6 \pm 0,8) \%$ до $(45,3 \pm 1,4) \%, p<0,05)$, тенденцію до зростання питомої ваги $\mathrm{CD}_{3-}$-клітин $(3(57,4 \pm 0,4) \%$ до $(61,8 \pm 1,1)$ $\%)$ та питомої ваги $\mathrm{CD}_{4+}$-клітин $(3(39,9 \pm 0,7) \%$ до $(45,4 \pm 1,5) \%$, р<0,05); під впливом ДТК з також зріс

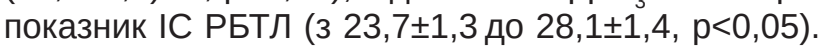
Окрім того, ФТЕ ДТК проявився зростанням показ-

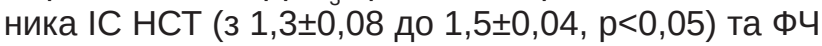
(відповідно $(50,6 \pm 1,5) \%$ та $(61,0 \pm 1,9) \%, p<0,05)$ і

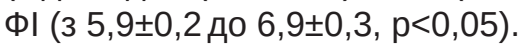

Досліджено вплив ДТК на стан сОМБ. 3'ясовано, що вміст альдегідних продуктів (АП $)$ сОМБ до лікування серед пацієнтів дослідних КГ коливався у межах від $(80,49 \pm 0,42)$ ум. од./мг білка до $(82,55 \pm 0,50)$ ум. од./мг білка та під впливом застосованих ДТК достовірно зменшувався. Вміст карбонільних продуктів (СП) сОМБ до лікування серед пацієнтів дослідних КГ коливався у межах від $(97,56 \pm 2,89)$ ум. од./мг білка до $(101,1 \pm 0,76)$ ум. од./мг білка та під впливом ДТК зменшувався на $(14,0 \pm 14,5) \%$. Аналіз рівнів ОДБ виявив, що до лікування пацієнти КГ відрізнялися лише за показником вмісту сОМБ середнього розміру (ідентифікуються при $\lambda=270$ нм) від хворих КГ 1 та КГ ${ }_{3}$, однак після лікування - найбільш виражене зниження рівня сОДБ виявлено у разі застосування ДТК

При іОМБ до лікування КГ 1 та КГ 2 не відрізнялись за показником вмісту альдегідних продуктів (АП,) та за КГ коливалось у межах від $(735,5 \pm 7,37)$ од. до $(773,3 \pm 8,84)$ од. (p>0,05), а застосування ДТК дозволяло знизити вміст АП, на $(16,5 \pm 17,8) \%$ та найбільш виразним був ФТЕ у КГ . Водночас, ФТЕ характеризувався найбільш вираженими змінами вмісту КП, в іОМБ саме серед пацієнтів КГ (до лікування - $(693,7 \pm 8,20)$ од., після $(565,3 \pm 19,8)$ од., p<0,001), тоді як у разі застосування ДТК та ДТК $\mathrm{T}_{2}$ - він був менш значимим. Також у КГ проведеного лікування в іОМБ виявлені значно менші резерви окисної модифрікація білкових фррагментів середнього розміру (до лікування $(0,401 \pm 0,011)$ од., після - $(0,297 \pm 0,022)$ од. $)$.

Також при вивченні рівнів окисної модифрікації нуклеїнових кислот (ОМНК) до та після застосування ДТК ${ }_{1-3}$ з'ясовано, що найбільш ефективним

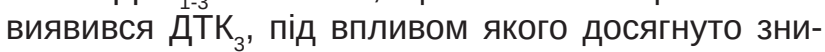
ження їх окиснення на 78,4 \%, тоді як у разі застосування ТДК - на 58,3 \%. ДТК

Аналіз біоенергетики клітин, який виконано за показниками вмісту аденілових нуклеотидів в еритроцитах периферичної венозної крові до та після застосування ДТК, не виявив статистично значимих відмінностей ( $>>0,05)$ між КГ за рівнем вмісту АТФ, АДФ, АМФ до початку лікування, тоді як під впливом застосованої терапії отримані достовірні ФТЕ щодо зростання рівня АТФ в КГ ${ }_{1-3}$, зростання рівня АДФ та достовірне зниження вмісту АМФ у всіх КГ. Найбільш вираженого ФТЕ досягнуто серед пацієнтів $\mathrm{KГ}_{3}$, середні значення вмісту АТФ у яких (після застосування ДТК ) зросли на 69,0 \%, вмісту АМФ знизились на 39,8 \%, а АДФ - зросли на 64,9\%.

\section{ВИСНОВКИ}

1. З'ясовано, що при використанні ДТК (препарат «Глутаргін») дещо зростає частота осіб 3 функціональною компенсацією (3 $(24,0 \pm 8,5) \%$, до $(40,0 \pm 9,8) \%, p>0,05)$ та зменшується питома вага хворих із реакціями метаболічного дисбалансу (3 
$(44,0 \pm 9,9) \%$ до $(28,0 \pm 9,0) \%, p>0,05)$; узагальнений індекс ефрективності у КГ 1 становить: І .ог $_{1,11 .}$ При використанні ДТК (препарат «Ербісол») достовірно зростає частота осіб із фрункціональною компенсацією (3 $(21,7 \pm 8,6)$ \% до $(47,8 \pm 10,4) \%$, p<0,05) та зменшується частка хворих із реакціями метаболічного дисбалансу (3 $(43,5 \pm 10,3) \%$ до $(21,7 \pm 8,6) \%, p<0,05)$; узагальнений індекс ефективності в КГ 2 становить: I $\mathrm{I}_{\text {.го }}=1,38$. При використанні ДТК бісол») достовірно зростає частота осіб із функціональною компенсацією (3 $(18,5 \pm 9,6) \%$ до $(51,9 \pm 9,3) \%, p<0,05)$ та зменшується частка хворих із реакціями метаболічного дисбалансу (3 $(48,1 \pm 9,6) \%$ до $(11,1 \pm 6,0) \%, p<0,01)$; узагальнений індекс ефрективності вКГ ${ }_{3}$ становить: $\mathrm{I}_{\text {Е.го }}=1,71$.

2. 3'ясовано, що при використанні ДТК (препарат «Глутаргін») дещо зростає частота хворих на XE $з$ імунорегуляторною компенсацією (до лікування $(16,0 \pm 3,7) \%$, після $(28,0 \pm 9,0) \%, p<0,05)$ та змен-

\section{СПИСОК ЛІТЕРАТУРИ}

1. Абакумова Ю. В. Физиологическое и патологическое свободнорадикальное окисление: сущность, методика распознавания, теоретическое и практическое значение / Ю. В. Абакумова // Врачевание и его методология. - Саратов, 1996. - С. 33.

2. Ардаматский Н. А., Методика определения фризиологического и патологического перекисного окисления / Н. А. Ардаматский, Ю. В. Абакумова, Е. Н. Корсунова // Экоген. - 1994. - № 4. - С. 9.

3. Classification and clinical phenomenology of compensatory reactions of contact-protective systems in patients with eczema / Methkal Ahmad Mahmoud Mamduh, L. V. Kuts, L. V. Cherkashyna [et al.] // Azerbaijan Medical Journal. - 2020. - Vol. 2. - P. 39-46.

4. Бєленічев І. Ф., Продукти вільнорадикального перекисного окиснення та методи їх ідентифрікації / І. Ф. Бєленічев, Є. Л. Левицький, С. І. Коваленко // Совр. пробл. токсикол. - 2002. - № 4. - С. 9-18.

5. Гаврилов Б. В., СФ-метрическое определение содержания ГПР в плазме крови / Б. В. Гаврилов, М. И. Мишкорудная // Лабораторное дело. - 1983. № 3. - С. 33-36.

6. Гаврилов Б. В. Анализ методов определения продуктов ПОЛ в сыворотке крови по тесту с ТБК / Б. В. Гаврилов А. Р. Гаврилова, Л. М. Мажуль // Вопросы медицинской химии. - 1987. - Т. 33, № 1. - С. 118-123.

7. Горбунов Н. В. Активация образования окиси азота, опосредованная метаботропными глутаматными рецепторами в первичных культурах клеток - зёрен мозжечка / Н. В. Горбунов // Бюлл. эксперимент. биол. и медицины. - 1995. - № 7. - С. 40-48.

8. Гуревич В. С. Сравнительный анализ двух методов определения активности супероксиддисмутазы / В. С. Гуревич, К. Н. Конторидинова, С. В. Шапилина // Лабораторное дело. - 1990. - № 4. - С. 44-47.

9. Окислительная модификация белков сыворотки крови человека. Методы ее определения / Е. Е. Дубини- шується питома вага хворих із реакціями імунорегуляторного дисбалансу (до $(36,0 \pm 9,6) \%$, після $(12,0 \pm 6,5) \%, p<0,05)$; узагальнений індекс ефективності в КГ становить: I ${ }_{1 . н 3}=1,63$. При використанні ДТК 2 (препарат «Ербісол») також $є$ тенденція до зростання частоти осіб з імунорегуляторною компенсацією (до $(21,7 \pm 8,6) \%$, після - $(39,1 \pm 10,2) \%$, p>0,05) та зменшується частка хворих із реакціями імунорегуляторного дисбалансу (до лікування $(30,4 \pm 9,6) \%$, після - $(8,7 \pm 5,9) \%, p<0,05)$; узагальнений індекс ефективності в КГ $\Gamma_{1}$ становить: $\mathrm{I}_{\mathrm{E.н3}}=1,31$. Аналогічними закономірностями характеризується ефрективність застосування ДТК (препарат «Глутаргін» + препарат «Ербісол»): достовірно зростає частота осіб з імунорегуляторною компенсацією (до лікування $(14,8 \pm 6,8) \%$, після - $(40,7 \pm 9,5) \%, p<0,01)$ і зменшується частка хворих із реакціями імунорегуляторного дисбалансу (до лікування $(40,7 \pm 9,5) \%$, після - $(11,1 \pm 6,0) \%, p<0,01)$; узагальнений індекс ефрективності в КГ ${ }_{1}$ становить: $\mathrm{I}_{\mathrm{E.H3}}=1,50$.

на, С. О. Бурмистров, Д. А. Ходов, И. С. Поротов // Вопр. мед. химии. - 1995. - Т. 42, № 1. - С. 24-26.

10. Костюк В. А. Простой и чувствительный метод определения супероксиддисмутазы, основанной на реакции окисления кверцетина / В. А. Костюк, А. И. Потапович, Ж. В. Ковалёва // Вопр. мед. химии. -1990. № 32. - C. 88-91.

11. Косухин А. Б. Экстракция липидов смесью гептан изопропанол для определения ДК / А. Б. Косухин, Б. С. Ахметова // Лаб. дело. - 1987. - № 5. - С. 335-337.

12. Лемешко В. В., Глутатионпероксидаза и глутатионтранссрераза / В.В.Лемешко, Ю. В. Никитченко, И. В. Евич // Український біохімічний журнал. - 1987. № 8. - С. 59-57.

13. Лищук В. А. Информатизация клинической медицине / В. А. Лищук // Клин. информатика и телемедицина. - 2004. - № 1. - С.7-13.

14. Прохорова М. И. Методы биохимических исследований / М. И. Прохорова. - Ленинград : ЛГУ, 1982. - 278 с.

15. Черкашина Л. В. Контактно-захисні системи при системних дерматозах: стан та патогенетична корекція при екземі (популяційно-етіологічні особливості, перекисне окислення ліпідів, оксидантно-антиоксидантна система, неспецифічний імунний захист, імуномодулятори) / Л. В. Черкашина, А. М. Біловол, С. П. Шкляр. ФОП Шлёмич С.Ф., 2008. - 204 с.

16. Черкашина Л. В. Дослідження фракторів ризику, розробка критеріїв та обґрунтування алгоритму прогнозування екземи на етапі первинної медичної допомоги / Л. В Черкашина // Український журнал медицини, біології та спорту. - 2018. - Т. 3, № 6(15). - С.180-187.

17. Черкашина Л. В. Оцінка якості медичної допомоги на первинному етапі її надання хворим на екзему: дослідження обсягів та оцінка адекватності лікувальнопрофрілактичних заходів / Л. В. Черкашина // Актуальні питання сучасної медицини: Вісник Української медичної стоматологічної академії. - 2018. - № 4(64). - С. 80-83. 


\section{REFERENCES}

1. Abakumova YuV. [Physiological and pathological free radical oxidation: essence, recognition technique, theoretical and practical significance]. Vrachevaniye i yego metodologiya, Saratov. 1996; 33. Russian.

2. Ardamatskiy NA, Abakumova YuV, Korsunova YeN. [Method for determining physiological and pathological peroxidation]. Ekogen. 1994;4: 9. Russian.

3. Methkal Ahmad Mahmoud Mamduh, Kuts, LV, Cherkashyna LV. Classification and clinical phenomenology of compensatory reactions of contact-protective systems in patients with eczema. Azerbaijan Medical Journal. 2020;2: 39-46. DOI: 10.34921/amj.2020.2.006

4. Byelenichev IF, Levytskyy YeL, Kovalenko, SI. [Products of free radical peroxidation and methods of their identification]. Sovremennye problemy toksykologii. 2002;4: 9-18. Ukrainian.

5. Gavrilov BV, Mishkorudnaya MI. [SF -- metric determination of the content of GPR in blood plasma]. Laboratornoye delo. 1983;3: 33-6. Russian.

6. Gavrilov BV, Gavrilova AR, Mazhul LM. [Analysis of methods for determining the products of lipid peroxidation in blood serum by the test with TBA]. Voprosy meditsinskoy khimii. 1987;33(1): 118-23. Russian.

7. Gorbunov NV. [Activation of nitric oxide production mediated by metabotropic glutamate receptors in primary cell cultures - cerebellar grains]. Byulleten eksperimentalnoy biologii i meditsiny. 1995;7: 40-8. Russian.

8. Gurevich VS, Kontoridinova KN, Shapilina SV. [Comparative analysis of two methods for determining the activity of superoxide dismutase]. Laboratornoye delo. 1990;4: 44-7. Russian.

9. Dubinina YeYe, Burmistrov SO, Khodov DA, Porotov IS. [Oxidative modification of human serum proteins. Methods for its determination]. Voprosy meditsinskoy khimii. 1995;42(1): 24-6. Russian.
10. Kostyuk VA, Potapovich Al, Kovalova ZhV. [A simple and sensitive method for the determination of superoxide dismutase based on the oxidation reaction of quercetin]. Voprosy meditsinskoy khimii. 1990;32: 88-91. Russian.

11. Kosukhin AB, Akhmetova BS. [Extraction of lipids with a mixture of heptane isopropanol for the determination of DC]. Laboratornoye delo. 1987;5: 335-7. Russian.

12. Lemeshko VV, Nykytchenko YuV, Evych YV. [Glutathione peroxidase and glutathione transferase]. Ukrainskyi biokhimichnyi zhurnal. 1987;8, 59-7. Ukrainian.

13. Lishchuk VA. [Informatization of clinical medicine I Klin. informatics and telemedicine]. Klinicheskaya informatika i telemeditsina. 2004;1: 7-13. Russian.

14. Prokhorova MI. Biochemical research methods. [Методы биохимических исследований] Leningrad: LGU (Leningrad State University); 1982. Russian.

15. Cherkashyna LV, Bilovol AM, Shklyar SP. Contactprotective systems in systemic dermatoses: condition and pathogenetic correction in eczema (population-etiological features, lipid peroxidation, oxidative/antioxidant system, nonspecific immune protection. [Контактно-захисні системи при системних дерматозах: стан та патогенетична корекція при екземі (популяційно-етіологічні особливості, перекисне окислення ліпідів, оксидантно- антиоксидантна система, неспецифічний імунний захист, імуномодулятори)] FOP Shlëmych S.F.; 2008. Ukrainian.

16. Cherkashyna LV. [Research of risk factors, development of criteria and substantiation of the algorithm for predicting eczema at the stage of primary care]. Ukrainskyi zhurnal medytsyny, biolohii ta sportu. 2018;3(6/15): 180-7. Ukrainian.

17. Cherkashyna LV. [Assessment of the quality of medical care at the initial stage of its provision to patients with eczema: a study of the volume and assessment of the adequacy of treatment and prevention measures]. Aktualni pytannia suchasnoi medytsyny: Visnyk Ukrainskoi medychnoi stomatolohichnoi akademii. 2018;4 (64): 80-3. Ukrainian. 